\title{
Article
}

\section{Risk Disclosure and Corporate Cash Holdings}

\author{
Issal Haj-Salem ${ }^{1}$ (D) and Khaled Hussainey ${ }^{2, *(D)}$ \\ 1 Department of Accounting, Institute of Higher Commercial Studies of Carthage, University of Carthage, \\ Carthage 1054, Tunisia; issal.hajsalem@gmail.com \\ 2 Accounting and Financial Management Group, Faculty of Business and Law, University of Portsmouth, \\ Portsmouth PO1 3DE, UK \\ * Correspondence: Khaled.Hussainey@port.ac.uk; Tel.: +44-239-2844-715
}

Citation: Haj-Salem, Issal, and Khaled Hussainey. 2021. Risk Disclosure and Corporate Cash Holdings. Journal of Risk and Financial Management 14: 328. https:// doi.org/10.3390/jrfm14070328

Academic Editors: Mohamed H. Elmagrhi and Erhan Kilinçarslan

Received: 17 June 2021

Accepted: 13 July 2021

Published: 15 July 2021

Publisher's Note: MDPI stays neutral with regard to jurisdictional claims in published maps and institutional affiliations.

Copyright: (c) 2021 by the authors. Licensee MDPI, Basel, Switzerland. This article is an open access article distributed under the terms and conditions of the Creative Commons Attribution (CC BY) license (https:/ / creativecommons.org/licenses/by/ $4.0 /)$.

\begin{abstract}
In this paper, we extend corporate disclosure and corporate cash holdings literature by testing whether corporate voluntary risk disclosure affects corporate cash holdings for a sample of Tunisian non-financial listed companies. As a measure of risk disclosure, we use manual content analysis to count the number of risk-related sentences in the narrative sections of corporate annual reports. As a measure of corporate cash holdings, we use the ratio of cash and cash equivalent over the total assets. Using a sample of 140 firm-year observations for the period of 2008-2013, we find that corporate risk disclosure has a negative impact on corporate cash holdings. Our results are consistent with agency, legitimacy and impression management theories. Our paper adds to the existing literature by being the first empirical evidence for the impact of risk disclosure on cash holdings. Our findings offer policy implications relevant for the current debate on the reliability of narrative risk disclosure and whether managers inform or obfuscate stakeholders by disclosing more risk-related information in their annual report narratives.
\end{abstract}

Keywords: risk disclosure; cash holdings; content analysis; Tunisian listed companies

\section{Introduction}

Holding cash is one of the financial decisions that attracts the attention of a large number of accounting and financial studies due to its micro- and macro-economic consequences. In finance literature and in practice, we consider cash as the 'King' in the business environment since it has a direct influence on the firm value and also determines financing, operations, investments and payouts (Chen et al. 2020). Cash is a liquid asset that provides firms with the necessary liquidity for a potential investment or to overcome a span cash deficit (Opler et al. 1999). Holding cash, mainly, allows companies to benefit from lower transaction costs and/or to face unpredicted contingencies (Keynes 2018). Nevertheless, prior studies have argued that cash holdings lead to managerial opportunistic behavior (Farinha et al. 2018; Tran 2020). In this sense, and according to agency theory, conflicts of interest may arise among managers and shareholders (Jensen and Meckling 1976; Jensen 1986). Managers are likely to stockpile cash to increase their autonomy and to serve their private interests rather than the firm's interests (Opler et al. 1999). This may lead them to make investments in unprofitable projects that serve their benefits. Thus, it is crucial to limit managerial opportunistic behavior. The extant literature shows that risk disclosure is an effective mechanism that reduces information asymmetry between managers and owners and consequently agency problems (e.g., Alzead and Hussainey 2017; Salem et al. 2019). Recent disclosure studies (e.g., Chen et al. 2020; Lu et al. 2017) have focused on the impact of corporate social responsibility (CSR) disclosure on cash holdings and offer mixed findings. To the best of our knowledge, no study, to date, has been undertaken to explore the potential impact of risk disclosure on cash holdings. Our paper is in the spirit of Khatib et al.'s (2021) call for research designed to assess the cash holdings-corporate disclosure relationships. 
We focus on risk disclosure and its potential impact on cash holdings as there is limited literature that links the concept of risk with cash holdings. For example, Cheung (2016, p. 412) argued that "lower systematic risk may increase or decrease cash holdings. Although low systematic risk induces firms to reduce their cash holdings, it also induces firms to hold a short debt maturity structure, with higher refinancing risks that higher cash holdings may mitigate". In addition, Chen et al. (2020, p. 1) argue that "either deficit cash or excess cash would incur risk and uncertainty concerns for business"; therefore, identifying the optimal levels of cash is a key challenge for businesses. In our paper, we test to see if risk information in annual report narratives of Tunisian non-financial companies has an impact on the levels of cash holdings.

Tunisia offers an interesting context for our study to explore the risk disclosure-cash holdings relationship. Tunisia has experienced financial instability accentuated by political transitions. The year 2021 marked the 10th « anniversary » of the Arab Spring. The political instability has had a considerable impact on the evolution of financing granted by banks to companies, which has prompted them to seek different sources of financing, such as trade credit. Since 2011, Tunisia's sovereign rating by Moody's has deteriorated year over year. It went from BAA2 (Stable outlook) in 2013 to B3 (Negative outlook) in 2021. Recently, in March 2021, the Arab Institute of Business Leaders (IACE) highlighted the impact of this sovereign rating downgrade and its direct impacts on foreign investment, the financing of the economy, banks, and Tunisian companies. Further, this decrease was accompanied by a decrease in the investment rate too (from 21.9 percent in 2013 to 13 percent in 2020). Thus, Tunisia has experienced damaging contingencies accentuated by the COVID health crisis. These facts highlight the importance to find ways to "heal" the ills of the Tunisian economy.

Thus, our study examines whether corporate risk disclosure practice has an impact on cash holding policies, and accordingly if it could be an effective tool to refrain opportunistic behavior to increase firms' financial health. To investigate this issue, we use a sample of Tunisian listed non-financial companies during 2008-2013. The empirical findings of the fixed-effect model confirm that risk disclosure has a negative impact on cash holdings. Consequently, we conclude that risk disclosure mitigates the discretionary behavior of managers. Our results are robust after using quantile regressions and log transformation.

We believe that our study has several contributions. Firstly, studying risk disclosure in emerging markets and during a period of crisis is still rare in the literature. Moreover, we focus on cash holding policies that have recently attracted much attention in accounting studies. Furthermore, to the best of our knowledge, no study, to date, has investigated the association between risk disclosure and cash holdings. We provide the first empirical evidence on the impact of risk disclosure on corporate cash holdings.

The rest of this paper is organized as follows. Section 2 presents the literature review and the hypothesis development. Section 3 illustrates the research methodology. Section 4 discusses the empirical findings and the robustness checks. Section 5 concludes the paper.

\section{Literature Review and Hypothesis Development}

\subsection{Motivations of Cash Holding}

Through the literature, we can identify several motives for corporate cash holdings. These include precautionary, speculative and transactional motives (Keynes 2018). First, the precautionary motive is a response to the economic and financial development, and is intended to avoid potential damage. In this sense, cash is considered as a "shield » for adverse events (Opler et al. 2001) and a «buffer» to absorb adverse shocks (Ehling and Haushalter 2014). For instance, during periods of poor business conditions, holding cash increases the likelihood of survivorship (Han and Qiu 2007). Moreover, prior literature (e.g., Almeida et al. 2004; Song and Lee 2012) has found that the more companies are financially constrained, the more need there is for holding cash, since it may help companies to avoid high financing costs. Nurul Hoque et al. (2020) considers that the precautionary motive may lead to a dividend decrease and asset disposal as responses to the need for liquidity. 
Second, the transactional motive suggests that holding cash is essential to carry out current business activities, including considering the best use of any investment opportunity that might be raised, and consequently mitigates transaction and financing costs. In this sense, companies may easily take advantage of investment opportunities and avoid underinvestment (Mehrabanpour et al. 2020). Otherwise, organizations with downward fluctuating cash flows are likely to decline profitable investment projects (Guizani 2017).

Third, holding cash may have a speculative motive. Indeed, firms may use cash to invest in financial securities and to profit from the interest rate or amass capital gains. Given these motivations, there are also opportunity costs for cash holdings. Indeed, having a high cash level may lead to undervaluation by investors, and agency conflicts among managers and stakeholders due to inefficient investment and wasting cash on private interests (Martínez-Sola et al. 2013).

\subsection{Motivations of Risk Disclosure}

What drives companies to report risk information in their annual reports? This was one of the most important research questions that prior research has tried to offer an answer for. Different theories explain potential drivers for risk disclosure. These include information asymmetry theory, agency theory, signaling theory and legitimacy theory. Indeed, information asymmetry occurs when there is imperfect observability on a market and, therefore, one person recognizes more information, e.g., Diamond and Verrecchia (1991); Kim and Verrecchia (1994); Kothari (2008) found that disclosure mitigates the information asymmetry between insiders and outsiders. Besides, investors need to have useful and relevant information in order to enhance their confidence and to reduce the uncertainty regarding their investments (Diamond and Verrecchia 1991). Accordingly, higher risk disclosure leads to less information asymmetry since outsiders, generally, do not have access to this information (Elzahar and Hussainey 2012). Research on risk disclosure has shown that risk disclosure mitigates information asymmetry (Al-Hadi et al. 2016; Elshandidy and Neri 2015; Miihkinen 2013). Moreover, conflicts of interest could appear among managers and shareholders and/or shareholders and creditors. This conflict of interest associated with an information asymmetry gives rise to agency problems. For that, according to agency theory, risk disclosure is considered an effective means to alleviate the conflicts of interests and agency costs. Furthermore, managers could disseminate risk disclosure information in order to reassure shareholders about the risk management actions to overcome negative consequences and keep shareholders satisfied (Salem et al. 2019). Regarding the signaling theory (Spence 1974), risk disclosure is considered as an inescapable signal to stakeholders aiming to mitigate information asymmetry, which may have negative consequences leading either to too low valuations or a political sub-optimal investment. This practice may reflect a company's credibility and allow for making relevant decisions; especially when a company is faced with difficult circumstances or a disturbing environment, it is in its interest to provide risk-related information to the market as a signal and to also provide specific information about how it can manage this risk (Salem et al. 2019). Moreover, according to the legitimacy theory, when a company's reputation could be damaged, managers have to react and legitimate the company's situation. Therefore, managers can choose to disclose the dangers threatening the company and the means to be considered in order to overcome them. In this sense, Iatridis (2008) argues that managers may ensure a company's reputation by disclosing risk information and their managerial skills in such constrained situations, which in turn alleviate information asymmetry, litigation, and reputational costs.

Given the importance of corporate risk disclosure, many researchers have investigated this disclosure practice in different contexts, both developed and emerging ones. Nevertheless, the research lines in this area are increasingly divergent. Most studies have been conducted to understand the determinants of corporate risk disclosure (Abraham and Cox 2007; Al-Maghzom et al. 2016; Alkurdi et al. 2019; Alzead and Hussainey 2017; 
Beretta and Bozzolan 2004; Bufarwa et al. 2020; Elshandidy and Neri 2015) (Alzead and Hussainey 2017; Elshandidy and Shrives 2016; Elzahar and Hussainey 2012; Miihkinen 2012, 2013; Salem et al. 2019). Others explain its relevance and usefulness for investors (e.g., Deumes 2008; Miihkinen 2013). More recently, researchers focus on other lines such as the economic consequences of corporate risk disclosure (e.g., Haj-Salem et al. 2020). Based on prior researchers, we are convinced about the importance of corporate risk disclosure. However, since the importance of cash holding and the related potential opportunistic behavior of managers, we wonder if disclosing more risk information may have an impact on detaining cash. To the best of our knowledge, no study has investigated this issue and we aim by this research to fill this research gap.

\subsection{Hypothesis Development}

Cash holding is considered an essential factor for making investment decisions (Fama and French 2021). In the same sense, Lofton (2018) states that managers rely more on cash holdings rather than debt, even though both resources are available for firms. However, detaining cash could be related to the information asymmetry between insiders and outsiders (Martínez-Sola et al. 2018). Accordingly, risk disclosure, as a tool mitigating information asymmetry, may have an impact on firms' cash holding. To understand this potential relationship, we rely on several theories, but mainly pecking order theory, agency theory and trade-off theory.

Regarding the pecking order theory, Myers and Majluf (1984) state that firms are likely to prefer internal to external financing. Moreover, they believe that information asymmetry between managers and investors leads firms to hold cash to use internal funds, rather than debt, equity to take investment opportunities. This incentive aims to minimize the costs of both asymmetric information and external financing (Nurul Hoque et al. 2020).

Nevertheless, holding more cash leads to more managerial problems (Barrot 2016; Yang and Susanto 2020). According to the free cash flow hypothesis (Jensen 1986), managers are likely to hold cash to strengthen their control of these assets and to have discretionary power over investment decisions. Moreover, this discretionary power generates conflicts of interest among shareholders and managers since it may be a tool for the latter to have private benefits by diverting this cash or to make investment decisions that match their interest rather than their firm's interest (Nurul Hoque et al. 2020). Accordingly, and consistent with agency theory, self-interested managers are motivated to hold cash due to their risk aversion and/or to have better flexibility in managing their own goals (Mehrabanpour et al. 2020) by even using the firm's resources to make inefficient investments not in the shareholders' interests (Jensen and Meckling 1976; Jensen 1986; Myers and Rajan 1998).

Finally, the trade-off theory considers that holding cash enhances the likelihood of a company to make investment opportunities and to be less dependent on expensive external financing (Martínez-Sola et al. 2013). However, by holding cash, firms have to be aware of the opportunity and agency costs.

As a result, agency conflicts affect cash holding policies, since opportunistic managers have an incentive to detain cash to increase their own benefit (Liu et al. 2015). Accordingly, risk disclosure practices will probably have an inverse association with cash holding, since they may mitigate the discretionary power of opportunistic managers and enhance shareholder wealth. This is in accordance with the premises of the legitimacy theory too, which concludes that disclosing risk information decreases managers' opportunistic behavior and, therefore, their incentives to hold more cash reserves decrease too. Moreover, we believe that, according to impression management theory (Revsine 1991), managers may be telling the truth, since if the company faces harmful circumstances, the cash reserves will be lower. In fact, consistent with impression management theory, managers tend to be opportunistic and take advantage of private information to achieve their interests (Schleicher and Walker 2010). Hence, we expect that corporate risk disclosure has a negative impact on cash holdings. Accordingly, our hypothesis is formulated as follows: 
Hypothesis 1. Risk disclosure negatively affects the level of corporate cash holdings.

\section{Methodology}

\subsection{Sample and Data Collection}

We collected annual reports of Tunisian listed companies for the period 2008-2013. In Tunisia, serious political events have taken place since early 2014, which have had an impact on the socio-economic situation of the country. Such events probably affect both the levels of risk disclosure and the levels of cash holding. We therefore ended our sample in the year 2013.

Many reasons lead us to choose the Tunisian context for our study. Although many researchers have undertaken investigations on risk disclosure in the two last decades, the emerging market still needs more investigations compared to developed ones. Thus, a systematic literature review elaborated by Khlif and Hussainey (2016) highlighted this research gap. Moreover, extant literature (e.g., Shiau et al. 2018) has demonstrated the importance of cash holding strategies during constraint periods. Consequently, the association between risk disclosure and cash holding becomes questionable in such contexts. We end our period in 2013 to avoid the impact of the political system transition. In fact, in the year 2014, the legislative and presidential elections were undertaken, which are considered an official beginning for a democratic transition which, certainly, impacted the socio-economic situation of the country and accordingly the cash holding strategies of Tunisian companies.

We excluded financial companies due to their specific disclosure requirements. This is in line with prior studies on risk disclosure (Elshandidy and Neri 2015). Indeed, researchers consider financial companies as risk-oriented institutions compared to non-financial ones; accordingly, they should be studied independently (Al-Maghzom et al. 2016). We relied on annual reports to analyze risk disclosure, since annual reports used to be the most important communication means for stakeholders in making investment decisions (Botosan 1997). The annual reports were collected manually from the Financial Market Council (CMF) for 28 Tunisian listed non-financial companies (around 90 percent of all non-financial Tunisian listed companies). Nevertheless, it was crucial to remove the outliers in our sample to avoid biased results. Therefore, we used a Student's $t$-test to delete all observations with a $\mathrm{t}$ greater than 2 in absolute value. This selection procedure leaves us with a final sample of 140 firm-year observations. Table 1 illustrates our sample.

Table 1. Industries' sample.

\begin{tabular}{cc}
\hline Industry & Number of Firms \\
\hline Telecommunications & 1 \\
General retailers & 4 \\
Travel and leisure & 1 \\
Health & 2 \\
Consumer goods & 4 \\
Food and Beverage & 4 \\
Personal and household goods & 1 \\
Construction and materials & 4 \\
Industrial goods and services & 2 \\
Chemicals & 3 \\
Raw materials & 1 \\
Oil and Gas & 1 \\
\hline TOTAL & 28 \\
\hline Original sample & 168 \\
\hline (-) Missing reports & 19 \\
\hline (-) Outliers & 9 \\
\hline Final sample & 140 \\
\hline
\end{tabular}




\subsection{Measuring the Cash Holding}

The cash holding (CASH) was our dependent variable. Through the literature, we found different measures of cash holdings. It was measured as cash over total assets (Bates et al. 2009; Hanlon et al. 2017; Mehrabanpour et al. 2020). Moreover, other researchers (e.g., Bhuiyan and Hooks 2019; Chauhan et al. 2018) measured the cash holding by the sum of cash and marketable securities divided by total assets. For our study, we measure the cash holding as the ratio of cash and cash equivalent over total assets, following prior research (Al-Najjar and Clark 2017; Farinha et al. 2018; Ozkan and Ozkan 2004). The data were collected from the balance sheet.

\subsection{Measuring the Risk Disclosure}

The risk disclosure was our independent variable. It was measured through the content analysis approach from Tunisian annual reports. The content analysis was defined earlier as "a research technique for the objective, systematic and quantitative description of the manifest content of communication" (Berelson 1952). Accordingly, it is considered as a technique for making replicable and valid inferences from texts (or other meaningful matter) based on the contexts of their use (Krippendorff 2004). The manual content analysis was used following prior research (e.g., Salem et al. 2019). Moreover, the sentence is used as the analysis unit following, e.g., Abraham and Cox (2007); Beretta and Bozzolan (2004). Indeed, the sentence was considered better than words since the latter cannot reflect the meaning without the context of a sentence. We performed an unweighted content analysis approach that followed prior disclosure studies (e.g., Alotaibi and Hussainey 2016; Elzahar et al. 2015; Mcchlery and Hussainey 2021; Salem et al. 2019). For that, the value of 1 is attributed if a sentence contains risk information, and zero otherwise. We used the risk disclosure index developed by Haj-Salem et al. (2020). Their index was inspired from prior studies on risk disclosure (Linsley et al. 2006; Moumen et al. 2015) and adapted to the Tunisian context ("Appendix A"). The followed risk disclosure index is composed of 48 items classified into six categories (operations risk, empowerment risk, information processing and technology risk, integrity risk, strategic risk, and financial risk). After setting the content analysis method (manual), the research question (the existence of risk information), the codable document (annual reports), the coding unit (sentence), the disclosure categories (risk disclosure index as shown in Appendix A), and the coding mode (un-weighted approach), we then performed the content analysis. Moreover, several coding rules were followed; mainly, we relied on the risk disclosure definition advanced previously, we only retained explicit risk information, the classification into categories should be done according to the most emphasized category within the sentence, and we did not take into account any repeated risk information in the considered annual report. Finally, to overcome the weaknesses of manual content analysis, mainly its subjectivity, we checked for its reliability through stability, reproducibility and accuracy, according to Krippendorff (2004). We calculated Scott's pi using the "ReCal" online statistical software. The Scott's pi test average score for inter/intra-reliability was satisfactory (e.g., $87 \%$ ) compared to the level of 0.75 in prior studies (e.g., Abraham and Cox 2007; Linsley et al. 2006).

\subsection{Control Variables}

We controlled for Cash flow (CF_OP). This was measured by the operating cash flow scaled by total assets, following Chen et al. (2020). On the one hand, according to the trade-off theory, there is a negative impact of cash flow on cash holding. Indeed, companies having more operating cash flow are less likely to save cash reserves (Kim et al. 2011). On the other hand, in accordance with the pecking order theory, companies with higher cash flow are likely to stockpile more cash as internal financing investment and to overcome difficult circumstances (Bates et al. 2009; Ferreira and Vilela 2004; Uyar and Kuzey 2014). 
In addition, we controlled for capital expenditure (CAPEX), calculated as cash paid to purchase fixed assets, intangible assets, and other long-term assets, divided by total assets (Chen et al. 2020). We believe that the more it is, the less the company saves cash. In fact, according to the pecking order theory, cash reserves are the outcome of company investment decisions, and accordingly of capital expenditures. Hence, when the capital expenditures increase, the cash holding decreases (Dittmar et al. 2003). Accordingly, we expected to have a negative coefficient.

We also controlled for tangibility (TANG). This is measured by the ratio of tangible assets over total assets. We expected a negative coefficient, since the companies characterized by rich tangible capital are less likely to hoard cash (Drobetz and Grüninger 2007; Lei et al. 2018).

The Debt maturity (DEBTM) was used as a control variable. That is calculated as the ratio of long-term debt to total debt (García-Teruel and Martínez-Solano 2008). We expected to have a negative association between Debt maturity and cash holdings. Prior literature argued that using short-term debt leads companies to periodically negotiate their credit terms, which increases the external financing risk. Therefore, such companies need to save more cash to avoid the non-renewal of their credit and any potential financial distress (Ferreira and Vilela 2004).

We also controlled for Performance (ROE). Several studies used this in addition to other control variables, such as leverage, growth, etc. (e.g., Chen et al. 2020; Mehrabanpour et al. 2020). The performance is calculated as the ratio of net income to shareholders' equity. We expected a positive association between performance and cash holding, following prior studies (Abushammala and Sulaiman 2014; Mehrabanpour et al. 2020).

We also controlled for Net Working Capital (NWC). It is calculated as current assets minus current liabilities minus the sum of cash and marketable securities, scaled by the total assets (Chen et al. 2020). Prior research has demonstrated that cash holding and networking capital may have a substitution relationship (Bates et al. 2009; Ferreira and Vilela 2004). Thus, we expected a negative coefficient, following the empirical findings of Habib et al. (2017).

Finally, we controlled for Dividend (DIVPAID). It is a dummy variable that takes a value of 1 if dividends are paid during the fiscal year, and 0 otherwise (Clarkson et al. 2020). In accordance with the trade-off theory, we expected a negative association between dividend and cash. This has been confirmed empirically by several researchers (Al-Najjar 2013; Yang and Susanto 2020).

\subsection{Research Model}

To test our research hypothesis, whether there is a negative impact of risk disclosure (CRD) on cash holdings (CASH), we referred to the existing literature on cash holdings ${ }^{\prime}$ determinants (e.g., Chen et al. 2020), and we constructed the following model. All the measures of the variables explained in the previous sections are presented in Table 2.

Our empirical findings and robustness checks are presented in Section 4.

$$
\begin{gathered}
\text { T CASH } i, t=\alpha 0+\beta 1 \text { CRDi,t }+\beta 2 \text { CF_OPi,t }+\beta 3 \text { CAPEXi,t }+\beta 4 \text { TANGi,t } \\
+\beta 5 \text { DEBTMi,t }+\beta 6 \text { ROEi, } t+\beta 7 \text { NWC } i, t+\beta 8 \text { DIVPAID } i, t+\varepsilon
\end{gathered}
$$

where:

$\alpha=$ the intercept.

$\beta 1, \ldots, \beta 9=$ Regression coefficients.

$\varepsilon=$ Error term. 
Table 2. Variables' descriptions.

\begin{tabular}{|c|c|c|}
\hline Variable & Symbol & Description \\
\hline Cash holding & $\mathrm{CASH}$ & Cash and cash equivalent/Total assets \\
\hline $\begin{array}{l}\text { Corporate Risk } \\
\text { disclosure }\end{array}$ & CRD & $\begin{array}{l}\text { Risk disclosure index as described in } \\
\text { "Appendix A" }\end{array}$ \\
\hline Cash flow & CF_OP & $\begin{array}{l}\text { Operating cash flow/Total assets } \\
\text { Cash paid to purchase fixed assets }+\end{array}$ \\
\hline Capital expenditure & CAPEX & $\begin{array}{c}\text { intangible assets + other long-term } \\
\text { assets)/Total assets }\end{array}$ \\
\hline Tangibility & TANG & Tangible assets/Total assets \\
\hline Debt maturity & DEBTM & Long-term debt/total debt \\
\hline Performance & ROE & Net income to shareholders' equity \\
\hline Net Working Capital & NWC & $\begin{array}{c}\text { (Current assets - current liabilities - the } \\
\text { sum of cash and marketable } \\
\text { securities)/Total assets }\end{array}$ \\
\hline Dividend & DIVPAID & $\begin{array}{c}\text { A dummy variable that takes a value of } 1 \\
\text { if dividends are paid during the fiscal } \\
\text { year and } 0 \text { otherwise }\end{array}$ \\
\hline
\end{tabular}

\section{Empirical Analysis and Robustness Check}

\subsection{Descriptive Statistics}

Table 3 reports descriptive statistics of the continuous variables used in our study. During 2008-2013, the value of cash holdings was, on average, about 3\%. Overall, we may consider the level of cash holding is low for Tunisian listed companies compared with other contexts. For example, the level of cash holding is $17 \%$ in the US, $9.9 \%$ in the UK (Ozkan and Ozkan 2004), and 9.1\% in Turkey (Uyar and Kuzey 2014).

Table 3. Descriptive statistics for continuous variables.

\begin{tabular}{cccccc}
\hline Variable & Obs & Mean & Std. Dev. & Min & Max \\
\hline CASH & 140 & 0.03 & 0.04 & 0 & 0.35 \\
CRD & 140 & 5.02 & 3.27 & 1 & 18 \\
CF_OP & 140 & 0.08 & 0.19 & -0.33 & 1.9 \\
CAPEX & 140 & 0.08 & 0.12 & 0 & 0.87 \\
TANG & 140 & 0.99 & 0.01 & 0.93 & 1 \\
DEBTM & 140 & 0.25 & 0.18 & 0 & 0.72 \\
ROE & 140 & 0.16 & 0.21 & -0.28 & 0.85 \\
NWC & 140 & 0.13 & 0.68 & -1.52 & 7.12 \\
\hline
\end{tabular}

This table presents the correlations among the variables. All variables are defined in Table 2.

Furthermore, the CRD level for Tunisian-listed companies was relatively low, since the average was about 5.02. This is in line with prior works on risk disclosure in developing countries (e.g., Alotaibi and Hussainey 2016; Haj-Salem et al. 2020). The operating cash flow was about 0.08 . The capital expenditure had a mean of 8 percent. It varied from a minimum of 0 to a maximum of $87 \%$. Accordingly, the capital expenditure among Tunisian companies varied considerably. The mean value of tangibility was 99 percent. Accordingly, overall, the assets of Tunisian companies were composed of tangible assets. Regarding debt maturity, it varied between a minimum of 0 to a maximum value of 72 percent. Hence, the long-term debt of the companies of our sample represented on average 18 percent of the total debt. The majority of companies in our sample were making a profit, with a mean profitability ratio of 16 percent. The net working capital was about 13 percent. Table 4 shows the descriptive of our dummy variable (divpay). It shows that a total of 81.4 percent of companies were paying dividends during the fiscal year. 
Table 4. Descriptive statistics for the dummy variable.

\begin{tabular}{ccccc}
\hline & Proportion & Std. Err. & [95\%_Conf] & [Interval] \\
\hline divpaid & & & & \\
0 & 0.186 & 0.033 & 0.129 & 0.260 \\
1 & 0.814 & 0.033 & 0.740 & 0.871 \\
\hline
\end{tabular}

\subsection{Correlation Analysis}

Table 5 shows the Spearman correlation analysis among our study variables. We confirm the non-existence of multicollinearity, since no coefficient exceeds 0.8 . Moreover, we performed the variance inflation factors (VIF) as an additional check for multicollinearity (Table 6). No value is greater than 10. Accordingly, the multicollinearity assumption was not breached.

Table 5. Correlations matrix.

\begin{tabular}{cccccccccc}
\hline Variables & $\mathbf{( 1 )}$ & $\mathbf{( 2 )}$ & $\mathbf{( 3 )}$ & $\mathbf{( 4 )}$ & $\mathbf{( 5 )}$ & $\mathbf{( 6 )}$ & $\mathbf{( 7 )}$ & $\mathbf{( 8 )}$ & $\mathbf{( 9 )}$ \\
\hline (1) CASH & 1.00 & & & & & & & & \\
(2) CRD & 0.07 & 1.00 & & & & & & & \\
(3) CF_OP & $0.20^{*}$ & $-0.17^{*}$ & 1.00 & & & & & & \\
(4) CAPEX & 0.13 & -0.14 & $0.42^{*}$ & 1.00 & & & & \\
(5) TANG & $-0.17^{*}$ & 0.01 & -0.04 & $-0.22 *$ & 1.00 & & & \\
(6) DEBTM & $-0.29^{*}$ & $-0.27^{*}$ & -0.12 & -0.08 & 0.13 & 1.00 & & \\
(7) ROE & -0.15 & -0.02 & $0.17^{*}$ & 0.10 & 0.14 & -0.10 & 1.00 & & \\
(8) NWC & -0.12 & $-0.26^{*}$ & -0.08 & 0.00 & $0.27 *$ & $0.25^{*}$ & -0.01 & 1.00 & \\
(9) DIVPAID & 0.06 & $-0.20^{*}$ & 0.15 & $0.17^{*}$ & 0.16 & 0.08 & 0.11 & $0.27^{*}$ & 1.00 \\
\hline
\end{tabular}

This table demonstrates the correlations matrix among variables utilized in the study's model. All variables are defined in Table $1, *$ demonstrates the levels of significance at 0.05 .

Table 6. VIF.

\begin{tabular}{ccc}
\hline Variable & VIF & $\mathbf{1 / V I F}$ \\
\hline CAPEX & 1.32 & 0.76 \\
CF_OP & 1.31 & 0.77 \\
NWC & 1.27 & 0.79 \\
CRD & 1.22 & 0.82 \\
TANG & 1.21 & 0.83 \\
DEBTM & 1.17 & 0.85 \\
DIVPAID & 1.17 & 0.85 \\
ROE & 1.08 & 0.93 \\
\hline Mean VIF & 1.22 & \\
\hline
\end{tabular}

\subsection{Regression Results}

A panel data analysis was carried out. It was necessary to check, at the first stage, for omitted variables. The Ramsey test showed an F(3, 128) $=0.85$ and a Prob $>F=0.4565$. Hence, there was no problem with omitted variables. Then, we ran a specification panel test to decide between the pooled and unpooled estimation. The Chow test showed a prob $>\mathrm{F}=0.000$. Thus, an unpooled estimation was appropriate. However, the estimation through panel data can be performed in two ways: the fixed effect or random effect models. For that, we compared the two models using the Hausman test.

The generated results allow us to conclude that the fixed effect model is the most suitable (Prob $>$ chi $2=0.010$ ). Further tests were conducted to ensure the validity of the empirical findings and to avoid biased results. The homoscedasticity test was checked through the Modified Wald test for groupwise heteroscedasticity in the fixed effect regression model. We found a heteroscedasticity (chi2 $(28)=2062.40$; Prob $>$ chi2 $=0.000$ ) that has been corrected using the White (1980) method. Moreover, we tested for autocorrelation 
between residuals. We ran the Jochmans portmanteau test for within-group correlation in panel data. We found a Chi-sq $(14)=16.387$ and a Prob $>$ Chi-sq $=0.2903$, which confirm the lack of serial correlation.

The results of the fixed model are reported in Table 7 . We found a negative and significant association between CRD and cash holdings. Accordingly, our hypothesis is confirmed. Our findings allow us to conclude that the more a company discloses risk information, the less it stockpiles cash. This could be explained based on the free cash flow hypothesis (Jensen 1986), the agency theory and the legitimacy theory. Holding cash allows managers to strengthen their control and to have discretionary power over investment decisions. This generates conflicts of interest, since managers are likely to take advantage of this cash to realize private benefits rather than carrying out their firm's interest (Nurul Hoque et al. 2020). Consequently, the agency conflicts affect the cash holding policy, since opportunistic managers have an incentive to detain cash to increase their benefit (Liu et al. 2015). For that, the risk disclosure practices will moderate managers' opportunistic behavior and will have a negative impact on cash holding. Furthermore, according to the legitimacy theory, CRD mitigates managers' opportunistic behavior and, therefore, their incentives to stockpile high cash levels.

Table 7. Results.

\begin{tabular}{ccccccc}
\hline TC & Coef. & Std. Err. & $\mathbf{z}$ & $\mathbf{P}>\mathbf{z}$ & [95\% Conf. & Interval] \\
\hline CRD & $-0.0013064^{* *}$ & 0.0006142 & -2.13 & 0.033 & -0.0025103 & -0.0001026 \\
CF_OP & $0.0307512^{* *}$ & 0.0156924 & 1.96 & 0.050 & -0.00000533 & 0.0615078 \\
CAPEX & -0.0205307 & 0.0186897 & -1.10 & 0.272 & -0.0571619 & 0.0161005 \\
TANG & -0.2666149 & 0.1884719 & -1.41 & 0.157 & -0.636013 & 0.1027831 \\
DEBTM & $-0.0520447^{* * *}$ & 00.0097236 & -5.35 & 0.000 & -0.0711026 & -0.0329869 \\
ROE & $-0.0023076^{* * *}$ & 0.0004959 & -4.65 & 0.000 & -0.0032794 & -0.0013357 \\
NWC & $-0.0132666^{*}$ & 0.0071677 & -1.85 & 0.064 & -0.027315 & 0.0007817 \\
DIVPAID & 0.0065329 & 0.0046605 & 1.40 & 0.161 & -0.0026015 & 0.0156674 \\
Constant & $0.3072531^{*}$ & 0.1856894 & 1.65 & 0.098 & -0.0566915 & 0.6711978 \\
\hline
\end{tabular}

This table illustrates the findings of the fixed effect model after dealing with the heteroscedasticity problem. ${ }^{* * *}, * *$, and ${ }^{*}$ demonstrate the levels of significance at: $0.01,0.05$, and 0.10 , respectively.

Regarding control variables, the results show that cash flow is positively and significantly associated with cash holdings. This is consistent with our expectations and is in line with prior studies (e.g., Ferreira and Vilela 2004). The results could be explained in accordance with the pecking order theory, since companies with higher cash flow are likely to save more cash as internal financing investment (Bates et al. 2009)

Moreover, debt maturity, performance, and net working capital, respectively, are negatively and significantly associated with cash holdings. However, no association was found between capital expenditure, tangibility, dividend payment and cash holdings.

\subsection{Robustness Check}

To check the validity of our empirical findings, we performed a robustness check. Thus, we used log transformation, which allowed us to overcome any potential statistical issues such as non-normality and non-linearity. Moreover, quantile regressions were also conducted. The similarity of the results generated by these regressions (and reported in Table 8) confirm the robustness and validity of our findings. 
Table 8. Robustness check.

\begin{tabular}{|c|c|c|c|c|}
\hline & \multirow{2}{*}{ Results } & \multicolumn{3}{|c|}{ Robustness Check } \\
\hline & & Log Transformation & rreg & MM Regression \\
\hline \multirow[t]{2}{*}{ CRD } & $-0.001^{* *}$ & $-0.096^{* * *}$ & $-0.002 * *$ & $-0.001 * *$ \\
\hline & $(-2.13)$ & $(-3.01)$ & $(-2.27)$ & $(-2.11)$ \\
\hline \multirow{2}{*}{ CF_OP } & 0.031 * & $1.909 * * *$ & 0.016 & 0.019 \\
\hline & -1.96 & -2.7 & -0.79 & -1.04 \\
\hline \multirow[t]{2}{*}{ CAPEX } & -0.021 & -0.542 & $-0.025^{*}$ & -0.028 \\
\hline & $(-1.10)$ & $(-1.04)$ & $(-1.96)$ & $(-1.49)$ \\
\hline \multirow[t]{2}{*}{ TANG } & -0.267 & $-23.967^{* * *}$ & 0.007 & 0.065 \\
\hline & $(-1.41)$ & $(-2.99)$ & -0.04 & -0.29 \\
\hline \multirow[t]{2}{*}{ DEBTM } & $-0.052 * * *$ & $-2.986^{* * *}$ & $-0.041^{* * *}$ & $-0.039^{* * *}$ \\
\hline & $(-5.35)$ & $(-5.86)$ & $(-3.70)$ & $(-3.30)$ \\
\hline \multirow[t]{2}{*}{ ROE } & $-0.002 * * *$ & $-0.249 * * *$ & $-0.002^{* * *}$ & $-0.002 * * *$ \\
\hline & $(-4.65)$ & $(-6.73)$ & $(-6.54)$ & $(-2.64)$ \\
\hline \multirow[t]{2}{*}{ NWC } & $-0.013 *$ & 0.333 & $-0.022 * *$ & $-0.020^{* * *}$ \\
\hline & $(-1.85)$ & -1.19 & $(-2.43)$ & $(-3.05)$ \\
\hline \multirow[t]{2}{*}{ DIVPAID } & 0.007 & 0.185 & 0.002 & 0.004 \\
\hline & -1.4 & -0.79 & -0.26 & -0.76 \\
\hline \multirow[t]{2}{*}{ Constant } & 0.307 * & $20.791 * * *$ & 0.039 & -0.021 \\
\hline & -1.65 & -2.62 & -0.2 & $(-0.09)$ \\
\hline $\mathrm{N}$ & 140 & 140 & 140 & 140 \\
\hline $\mathrm{R}^{2}$ & & & 0.2 & MM regression \\
\hline adj. $R^{2}$ & & & 0.16 & $-0.001^{* *}$ \\
\hline
\end{tabular}

\section{Conclusions}

This study focuses on risk disclosure practices and their significant role in influencing cash holdings. We relied on the Tunisian context during the 2008-2013 period. The results of the fixed effect model show that the more risk disclosure of a company, the lower their cash reserves. Accordingly, risk disclosure alleviates information asymmetry and mitigates managerial discretionary behavior. Moreover, we believe that, according to impression management theory, managers are telling the truth, since if a company faces negative circumstances, the cash reserves will be lower. Our results are robust after using quantile regressions and a log transformation.

We believe that our study contributes to the existing literature in several ways. The first contribution is related to our context. In fact, investigating risk disclosure in emerging markets and during a period of distress still presents a gap in the literature. Moreover, recently, in the accounting field, there has been a growing number of investigations of cash holdings. Furthermore, to the best of our knowledge, no study, to date, has investigated the impact of risk disclosure on cash holdings.

Our study provides implications for Tunisian companies, since we demonstrated that risk disclosure moderates excess cash holdings and avoids potential managerial discretionary behavior. Accordingly, it is a tool to mitigate information asymmetry and to avoid «sleeping» money. Accordingly, our study could be relevant to regulatory bodies to set up rules enhancing risk disclosure.

Several limitations could be revealed for our study. Firstly, one limitation could be the relatively small sample. However, it is representative, since it includes almost all non-financial Tunisian listed companies. Secondly, the period of our study ends in the year 2013. This was due to legislative and presidential elections that took place in 2014; such political events could affect both corporate disclosure practices and levels of cash holdings. Thirdly, another limitation could be the subjectivity of manual content analysis. Thus, we checked for the reliability and validity of our disclosure scores.

Future research should focus on the association between risk disclosure and cash holdings in other contexts and periods. For that, more studies on the Tunisian context should be undertaken after the political system transition in the year 2014 or to compare the disclosure-cash holding relationship before and after the 2014 political events. Furthermore, researchers may investigate this association in different contexts and particularly during 
the global health crisis (the COVID-19 pandemic). Moreover, it could be interesting to study the moderating role of corporate governance mechanisms on this association.

Author Contributions: Conceptualization, I.H.-S. and K.H.; methodology, K.H.; software, I.H.-S.; validation, I.H.-S., K.H.; formal analysis, I.H.-S.; investigation, I.H.-S.; resources, I.H.-S.; data curation, I.H.-S.; writing-original draft preparation, I.H.-S.; writing-review and editing, K.H.; visualization, I.H.-S.; supervision, K.H. Both authors have read and agreed to the published version of the manuscript.

Funding: This research received no external funding.

Institutional Review Board Statement: Not applicable.

Informed Consent Statement: Not applicable.

Data Availability Statement: Data available on request due to restrictions.

Conflicts of Interest: The authors declare no conflict of interest.

\section{Appendix A}

Risk disclosure level index adopted from Haj-Salem et al. (2020).

Operations Risk

Customer Satisfaction

Product Development

Efficiency and Performance

Sourcing

Stock Obsolescence and Shrinkage

Product and Service Failure

Environmental

Health and Safety

Brand Name Erosion

Out of stock *

Quality of products *

Suppliers *

Employees *

Empowerment Risk

Leadership and Management

Outsourcing

Performance Incentives

Change Readiness

Communications

Control *

Information Processing and Technology Risk

Integrity

Access

Availability

Infrastructure

Integrity Risk

Management and Employee Fraud

Illegal Acts

Reputation

Litigation risk *

Strategic Risk

Environmental Scan

Industry

Business Portfolio

Competitors

Pricing

Valuation

Planning

Life Cycle

Performance Measurement

Regulatory

Sovereign and Political

Financial risk

Interest rate 


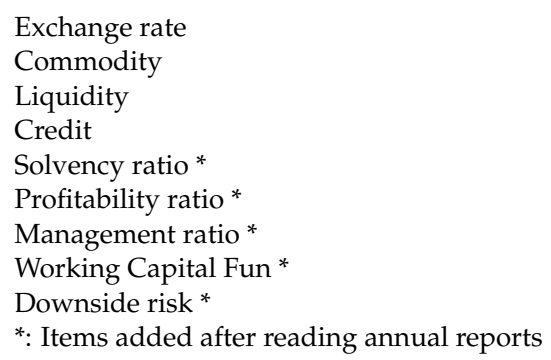

\section{References}

Abraham, Santhosh, and Paul Cox. 2007. Analysing the determinants of narrative risk information in UK FTSE 100 annual reports. The British Accounting Review 39: 227-48. [CrossRef]

Abushammala, Sami N. M., and Jamalludin Sulaiman. 2014. Cash holdings and corporate profitability: Some evidences form Jordan. International Journal of Innovation and Applied Studies 8: 898.

Al-Hadi, Ahmed, Mostafa Monzur Hasan, and Ahsan Habib. 2016. Risk Committee, Firm Life Cycle, and Market Risk Disclosures. Corporate Governance: An International Review 24: 145-70. [CrossRef]

Alkurdi, Amneh, Khaled Hussainey, Yasean Tahat, and Mohammad Aladwan. 2019. The impact of corporate governance on risk disclosure: Jordanian evidence. Academy of Accounting and Financial Studies Journal 23: 1-16.

Al-Maghzom, Abdullah, Khaled Hussainey, and Doaa A. Aly. 2016. Corporate governance and risk disclosure: Evidence from Saudi Arabia. Corporate Ownership and Control Journal 13: 145-66. [CrossRef]

Almeida, Heitor, Murillo Campello, and Michael S. Weisbach. 2004. The cash flow sensitivity of cash. The Journal of Finance 59: 1777-804. [CrossRef]

Al-Najjar, Basil. 2013. The financial determinants of corporate cash holdings: Evidence from some emerging markets. International Business Review 22: 77-88. [CrossRef]

Al-Najjar, Basil, and Ephraim Clark. 2017. Corporate governance and cash holdings in MENA: Evidence from internal and external governance practices. Research in International Business and Finance 39: 1-12. [CrossRef]

Alotaibi, Khaleed, and Khaled Hussainey. 2016. Determinants of CSR disclosure quantity and quality: Evidence from non-financial listed firms in Saudi Arabia. International Journal of Disclosure and Governance 13: 364-93. [CrossRef]

Alzead, Ramzi, and Khaled Hussainey. 2017. Risk disclosure practice in Saudi non-financial listed companies. Corporate Ownership and Control 14: 262-75. [CrossRef]

Barrot, Jean-Noel. 2016. Trade credit and industry dynamics: Evidence from trucking firms. The Journal of Finance 71: 1975-2016. [CrossRef]

Bates, Thomas W., Kathleen M. Kahle, and René M. Stulz. 2009. Why do US firms hold so much more cash than they used to? The Journal of Finance 64: 1985-2021. [CrossRef]

Berelson, Bernard. 1952. Content Analysis in Communication Research. New York: Free Press.

Beretta, Sergio, and Saverio Bozzolan. 2004. A framework for the analysis of firm risk communication. The International Journal of Accounting 39: 265-88. [CrossRef]

Bhuiyan, Md Borhan Uddin, and Jill Hooks. 2019. Cash holding and over-investment behavior in firms with problem directors. International Review of Economics \& Finance 61: 35-51. [CrossRef]

Botosan, Christine A. 1997. Disclosure level and the cost of equity capital. Accounting Review 72: 323-49.

Bufarwa, Idris M., Ahmed A. Elamer, Collins G. Ntim, and Aws AlHares. 2020. Gender diversity, corporate governance and financial risk disclosure in the UK. International Journal of Law and Management 62: 521-38. [CrossRef]

Chauhan, Yogesh, Rajesh Pathak, and Satish Kumar. 2018. Do bank-appointed directors affect corporate cash holding? International Review of Economics \& Finance 53: 39-56. [CrossRef]

Chen, Hanwen, Daoguang Yang, Joseph H. Zhang, and Haiyan Zhou. 2020. Internal controls, risk management, and cash holdings. Journal of Corporate Finance 64: 101695. [CrossRef]

Cheung, Adrian. 2016. Corporate social responsibility and corporate cash holdings. Journal of Corporate Finance 37: 412-30. [CrossRef]

Clarkson, Peter, Ru Gao, and Kathleen Herbohn. 2020. The relationship between a firm's information environment and its cash holding decision. Journal of Contemporary Accounting \& Economics 16: 100201. [CrossRef]

Deumes, Rogier. 2008. Corporate risk reporting: A content analysis of narrative risk disclosures in prospectuses. Journal of Business Communication 45: 120-57. [CrossRef]

Diamond, Douglas W., and Robert E. Verrecchia. 1991. Disclosure, liquidity, and the cost of capital. The Journal of Finance 46: 1325-59. [CrossRef]

Dittmar, Amy, Jan Mahrt-Smith, and Henri Servaes. 2003. International corporate governance and corporate cash holdings. Journal of Financial and Quantitative Analysis 38: 111-33. [CrossRef]

Drobetz, Wolfgang, and Matthias C. Grüninger. 2007. Corporate cash holdings: Evidence from Switzerland. Financial Markets and Portfolio Management 21: 293-324. [CrossRef]

Ehling, Paul, and David Haushalter. 2014. When Does Cash Matter? Evidence for Private Firms. Banco de Espana Working Paper No. 1412. Available online: https:/ / ssrn.com/abstract=2454015 (accessed on 17 June 2021). 
Elshandidy, Tamer, and Lorenzo Neri. 2015. Corporate governance, risk disclosure practices, and market liquidity: Comparative evidence from the UK and Italy. Corporate Governance: An International Review 23: 331-56. [CrossRef]

Elshandidy, Tamer, and Philip J Shrives. 2016. Environmental incentives for and usefulness of textual risk reporting: Evidence from Germany. The International Journal of Accounting 51: 464-86. [CrossRef]

Elzahar, Hany, and Khaled Hussainey. 2012. Determinants of narrative risk disclosures in UK interim reports. The Journal of Risk Finance 13: 133-47. [CrossRef]

Elzahar, Hany, Khaled Hussainey, Francesco Mazzi, and Ioannis Tsalavoutas. 2015. Economic consequences of key performance indicators' disclosure quality. International Review of Financial Analysis 39: 96-112. [CrossRef]

Fama, Eugene F., and Kenneth R. French. 2021. Financing Decisions Who Issues Stock? Chicago: University of Chicago Press.

Farinha, Jorge, Cesario Mateus, and Nuno Soares. 2018. Cash holdings and earnings quality: Evidence from the Main and Alternative UK markets. International Review of Financial Analysis 56: 238-52. [CrossRef]

Ferreira, Miguel A., and Antonio S. Vilela. 2004. Why do firms hold cash? Evidence from EMU countries. European Financial Management 10: 295-319. [CrossRef]

García-Teruel, Pedro J., and Pedro Martínez-Solano. 2008. On thedeterminants of SME cash holdings: Evidence from Spain. Journal of Business Finance E Accounting 35: 127-49. [CrossRef]

Guizani, Muncef. 2017. The financial determinants of corporate cash holdings in an oil rich country: Evidence from Kingdom of Saudi Arabia. Borsa Istanbul Review 17: 133-43. [CrossRef]

Habib, Ahsan, Mostafa Monzur Hasan, and Ahmed Al-Hadi. 2017. Financial statement comparability and corporate cash holdings. Journal of Contemporary Accounting E Economics 13: 304-21. [CrossRef]

Haj-Salem, Issal, Salma Damak Ayadi, and Khaled Hussainey. 2020. The joint effect of corporate risk disclosure and corporate governance on firm value. International Journal of Disclosure and Governance 17: 123-40. [CrossRef]

Han, Seungjin, and Jiaping Qiu. 2007. Corporate precautionary cash holdings. Journal of Corporate Finance 13: 43-57. [CrossRef]

Hanlon, Michelle, Edward L. Maydew, and Daniel Saavedra. 2017. The taxman cometh: Does tax uncertainty affect corporate cash holdings? Review of Accounting Studies 22: 1198-228. [CrossRef]

Iatridis, George. 2008. Accounting disclosure and firms' financial attributes: Evidence from the UK stock market. International Review of Financial Analysis 17: 219-41. [CrossRef]

Jensen, Michael C. 1986. Agency costs of free cash flow, corporate finance, and takeovers. The American Economic Review 76: 323-29.

Jensen, Michael C., and William H. Meckling. 1976. Theory of the firm: Managerial behavior, agency costs and ownership structure. Journal of Financial Economics 3: 305-60. [CrossRef]

Keynes, John Maynard. 2018. The General Theory of Employment, Interest, and Money. London: Palgrave Macmillan.

Khatib, Saleh F. A., Dewi Fariha Abdullah, Ernie Hendrawaty, and Ahmed A. Elamer. 2021. A bibliometric analysis of cash holdings literature: Current status, development, and agenda for future research. Management Review Quarterly, 1-38. [CrossRef]

Khlif, Hichem, and Khaled Hussainey. 2016. The association between risk disclosure and firm characteristics: A meta-analysis. Journal of Risk Research 19: 181-211. [CrossRef]

Kim, Oliver, and Robert E. Verrecchia. 1994. Market liquidity and volume around earnings announcements. Journal of Accounting and Economics 17: 41-67. [CrossRef]

Kim, Jiyoung, Hyunjoon Kim, and David Woods. 2011. Determinants of corporate cash-holding levels: An empirical examination of the restaurant industry. International Journal of Hospitality Management 30: 568-74. [CrossRef]

Kothari, Ashish. 2008. Protected areas and people: The future of the past. Parks 17: 23-34.

Krippendorff, Klaus. 2004. Reliability in content analysis: Some common misconceptions and recommendations. Human Communication Research 30: 411-33. [CrossRef]

Lei, Jin, Jiaping Qiu, and Chi Wan. 2018. Asset tangibility, cash holdings, and financial development. Journal of Corporate Finance 50: 223-42. [CrossRef]

Linsley, Philip M., Phillip J. Shrives, and Mandy Crumpton. 2006. Risk disclosure: An exploratory study of UK and Canadian banks. Journal of Banking Regulation 7: 268-82. [CrossRef]

Liu, Qigui, Tianpei Luo, and Gary Gang Tian. 2015. Family control and corporate cash holdings: Evidence from China. Journal of Corporate Finance 31: 220-45. [CrossRef]

Lofton, Michelle Lynn. 2018. Three Essays on the Management of Local Government Cash Flows. Ph.D. thesis, Syracuse University, Syracuse, NY, USA.

Lu, Louise Yi, Greg Shailer, and Yangxin Yu. 2017. Corporate social responsibility disclosure and the value of cash holdings. European Accounting Review 26: 729-53. [CrossRef]

Martínez-Sola, Cristina, Pedro J García-Teruel, and Pedro Martínez-Solano. 2013. Corporate cash holding and firm value. Applied Economics 45: 161-70. [CrossRef]

Martínez-Sola, Cristina, Pedro J. García-Teruel, and Pedro Martínez-Solano. 2018. Cash holdings in SMEs: Speed of adjustment, growth and financing. Small Business Economics 51: 823-42. [CrossRef]

Mcchlery, Stuart, and Khaled Hussainey. 2021. Risk disclosure behaviour: Evidence from the UK extractive industry. Journal of Applied Accounting Research 22: 484-506. [CrossRef] 
Mehrabanpour, Mohammadreza, Omid Faraji, Reza Sajadpour, and Mohammad Alipour. 2020. Financial statement comparability and cash holdings: The mediating role of disclosure quality and financing constraints. Journal of Financial Reporting and Accounting 18: 615-37. [CrossRef]

Miihkinen, Antti. 2012. What drives quality of firm risk disclosure? The International Journal of Accounting 47: 437-68. [CrossRef]

Miihkinen, Antti. 2013. The usefulness of firm risk disclosures under different firm riskiness, investor-interest, and market conditions: New evidence from Finland. Advances in Accounting 29: 312-31. [CrossRef]

Moumen, Néjia, Hakim Ben Othman, and Khaled Hussainey. 2015. The value relevance of risk disclosure in annual reports: Evidence from MENA emerging markets. Research in International Business and Finance 34: 177-204. [CrossRef]

Myers, Stewart C., and Nicholas S. Majluf. 1984. Corporate financing and investment decisions when firms have information that investors do not have. Journal of Financial Economics 13: 187-221. [CrossRef]

Myers, Stewart C., and Raghuram G. Rajan. 1998. The paradox of liquidity. The Quarterly Journal of Economics 113: 733-71. [CrossRef]

Nurul Hoque, Muhammad, Md Borhan Uddin Bhuiyan, Takumi Nomura, and Tony van Zijl. 2020. Determinants of cash holdingsEvidence from New Zealand local councils. Public Money \& Management. in press. [CrossRef]

Opler, Tim, Lee Pinkowitz, René Stulz, and Rohan Williamson. 1999. The determinants and implications of corporate cash holdings. Journal of Financial Economics 52: 3-46. [CrossRef]

Opler, Tim, Lee Pinkowitz, René Stulz, and Rohan Williamson. 2001. Corporate cash holdings. Journal of Applied Corporate Finance 14: 55-67. [CrossRef]

Ozkan, Aydin, and Neslihan Ozkan. 2004. Corporate cash holdings: An empirical investigation of UK companies. Journal of Banking $\mathcal{E}$ Finance 28: 2103-34. [CrossRef]

Revsine, Lawrence. 1991. The selective financial misrepresentation hypothesis. Accounting Horizons 5: 16.

Salem, Issal Haj, Salma Damak Ayadi, and Khaled Hussainey. 2019. Corporate governance and risk disclosure quality: Tunisian evidence. Journal of Accounting in Emerging Economies 9: 567-602. [CrossRef]

Schleicher, Thomas, and Martin Walker. 2010. Bias in the tone of forward-looking narratives. Accounting and Business Research 40: 371-90. [CrossRef]

Shiau, Huey-Ling, Yung-Ho Chang, and Yi-Jing Yang. 2018. The cash holdings and corporate investment surrounding financial crisis: The cases of China and Taiwan. The Chinese Economy 51: 175-207. [CrossRef]

Song, Kyojik, and Youngjoo Lee. 2012. Long-term effects of a financial crisis: Evidence from cash holdings of East Asian firms. Journal of Financial and Quantitative Analysis 47: 617-41. [CrossRef]

Spence, Michael. 1974. Market Signaling: Informational Transfer in Hiring and Related Screening Processes. Cambridge: Harvard University Press.

Tran, Quoc Trung. 2020. Corporate cash holdings and financial crisis: New evidence from an emerging market. Eurasian Business Review 10: 271-285. [CrossRef]

Uyar, Ali, and Cemil Kuzey. 2014. Determinants of corporate cash holdings: Evidence from the emerging market of Turkey. Applied Economics 46: 1035-48. [CrossRef]

White, Halbert. 1980. A heteroskedasticity-consistent covariance matrix estimator and a direct test for heteroskedasticity. Econometrica 48: 817-838. [CrossRef]

Yang, Ann Shawing, and Giovanny Cyntia Susanto. 2020. Corporate social responsibility and cash holding: Evidence from trucking firms. Applied Economics Letters 28: 85-89. [CrossRef] 